\title{
Ability of School Head Management in Application-Based Facilities and Infrastructure Management to Improve Education Quality in Harmoni State High School Pamona Utara Sub- District, Poso District
}

\author{
$1^{\text {st }}$ Mahfud M. Gamar \\ Historical Education \\ Universitas Tadulako \\ Central Sulawesi, Indonesia \\ mahfud_mahmud@untad.ac.id
}

\author{
$2^{\text {nd }}$ Shintya Yuliarni Sengkei \\ Historical Education \\ Universitas Tadulako \\ Central Sulawesi, Indonesia
}

\author{
$3^{\text {rd }}$ Misnah \\ Historical Education \\ Universitas Tadulako \\ Central Sulawesi, Indonesia
}

\begin{abstract}
The problem in this research is to explain the principal's managerial ability in the management of facilities and infrastructure in Harmoni State High School and explain the stages in the management of facilities and infrastructure. The sample questionnaire in this study was 10 teachers including the principal. Data collected through observation, interviews, questionnaires and documentation. The research data were analyzed with qualitative descriptive analysis and questionnaire data interpretation. Descriptive analysis results show that school principals can organize and develop school resources to create an effective and efficient learning environment. Educational resources include personnel, funds, facilities and infrastructure as well as available information. The stages in management, namely the planning, procurement, distribution, maintenance and supervision stages are carried out properly. The results of data interpretation show the calculation of the percentage according to the Likert scale, then each stage is obtained, namely the planning stage $90.2 \%$, the procurement phase $90.3 \%$, the distribution stage $70.3 \%$, the maintenance stage $78.7 \%$ so that the average management phase for facilities and infrastructure carried out by principals in high schools Harmony Country that is $82.375 \%$ or good.
\end{abstract}

Keywords-School Head, Management, Application-Based Facilities, Infrastructure, education quality

\section{INTRODUCTION}

The principal is one of the education components that has the most role in improving the quality of education. Each school principal has full responsibility for all aspects of operational school administration, from planning, organizing, implementing, to supervision. In order to carry out this task, a school principal is required to have personal, managerial, entrepreneurial, supervisory, and social competence [1].

School infrastructure is an important component in the education system. Sometimes the community even assesses the quality of education of a school by looking at infrastructure, schools that have large buildings, equipment and teaching and learning equipment that are complete and modern are often seen as quality schools. In this regard, the management of educational infrastructure in schools is very important so that there is no waste, nor is there any disruption to the smooth teaching and learning process because there are no facilities and infrastructure needed by teachers and students. Infrastructure facilities must be managed properly, because it is one of the factors supporting the implementation of the program in schools [2].

Management of educational facilities and infrastructure can be defined as the process of collaborative utilization of all educational facilities and infrastructure effectively and efficiently. This definition shows that the facilities and infrastructure that exist in schools need to be utilized and managed for the benefit of the learning process at school. The management is intended so that the use of facilities and infrastructure in schools can run effectively and efficiently. The management of facilities and infrastructure in schools requires a process as contained in management in general, which starts from planning, organizing, mobilizing, and supervising.

In the management or management of schools, especially in the field of facilities and infrastructure, it certainly cannot be separated from the responsibility of school principals as leaders and decision makers in schools starting from the planning, procurement, maintenance, and control of existing facilities and infrastructure. Management of facilities and infrastructure is essentially the entire structuring process that is closely related to the procurement, utilization and management of educational facilities for professionalism and the implementation of education effectively and efficiently [3] 
Therefore, based on these observations it draws the attention of the author to conduct research in state high schools Harmoni to study more deeply about "Principal's Managerial Ability in the Management of Facilities and Infrastructure to Improve the Quality of Education in Harmoni State High School".

Implementation of the industrial era 4.0 in all components of the administration of education is an absolute must. Therefore, although infrastructure support such as electricity resources and internet networks is inadequate, the infrastructure system for infrastructure facilities is still sought by the school principal. The use of asset management applications is relevant in the digitalisation era like today [4]. Asset management including advice and infrastructure is part of technology management. The increase in the speed of information technology must be commensurate with improvements in the database of facilities and infrastructure in schools. Data-based infrastructure management in the application is very helpful for principals and teachers in controlling the needs and needs of facilities and infrastructure for learning activities [5].

The purpose of this study is to describe the principal's managerial ability in the management of facilities and infrastructure to improve the quality of education and to know the stages of management of facilities and infrastructure.

The benefit of this research is that this research is expected to be able to contribute to students, especially education students in the field of education management related to the management of school facilities and infrastructure and can provide information or can be used as a reference in improving school management which includes management, utilization and development of educational facilities and infrastructure.

\section{RESEARCH METHOD}

This research uses a qualitative descriptive approach that is to dig as much data as possible from the object under study. Research aims to describe in the description, summarize the various conditions found in the field or object of research. Qualitative research aims to explain the phenomenon profusely through deep data collection, and this research does not prioritize population size or sampling even population or sampling is very limited.

This research was conducted at Harmoni State High School, Sulewana Village, Pamona Utara District, Poso Regency. This school is directly adjacent to the north with Jalan Trans Sulawesi, south of the dormitory building at Palindondaya Vocational School, west of the North Pamona District Office, east of the Sulewana Village Health Center. The research process is carried out in stages starting from the planning and preparation of instruments, testing of research instruments followed by field data collection as a core research activity, the time span of the research needed as a whole is from 1 to 30 May 2019.

The methods used are interview, questionnaire, observation and documentation. The sample is a portion or representative of the individual to be studied. The sample used was purposive sampling. This sampling technique is quite often used, this method uses criteria that have been selected by researchers in selecting samples. The sample selection criteria are exclusion criteria. The inclusion criterion was the sample criteria that the researchers wanted based on the research objectives, so that the sample in this study consisted of 10 teachers consisting of school principals, infrastructure representatives, school treasurers, library heads, laboratory heads, administrative staff, 2 science subject teachers and 2 IPS subject teachers.

The type of data used in this study are primary data and secondary data. Primary data is data taken from the first source (informant). Primary data in the form of interviews related to school facilities and infrastructure. Secondary data is data collected from the relevant agencies. Secondary data in this study one of them in the form of documentation of the condition of existing facilities and infrastructure.

Data analysis technique is done by using descriptive qualitative analysis, which is trying to describe or explain what the findings are in the field from the results of interviews and observations (observations). The formula that will be used to determine the percentage of achievement scores on each variable is as follows:

$$
\begin{aligned}
& \mathrm{P}=\frac{f}{N} \mathrm{X} 100 \% \\
& \text { (Thalib, M.M, M.Pd, 2009:17) }
\end{aligned}
$$

\section{Information: \\ P: Percentage \\ F: Number of frequencies \\ $\mathrm{N}$ : Number of observation items}

After obtaining the percentage results from the questionnaire distributed to teachers, then to determine the assessment categories of the results of the study, researchers formulated as follows:

TABLE I. PERSENTAGE INTERPRETATION

\begin{tabular}{|c|l|l|}
\hline No & \multicolumn{1}{|c|}{ Persentage } & \multicolumn{1}{c|}{ Interpretation } \\
\hline 1 & $100 \%$ & All of it \\
\hline 2 & $90 \%-99 \%$ & Almost all \\
\hline 3 & $60 \%-89 \%$ & Most of the \\
\hline 4 & $51 \%-59 \%$ & More than half \\
\hline 5 & $50 \%$ & Shall of it \\
\hline 6 & $40 \%-49 \%$ & Nearly half \\
\hline 7 & $10 \%-39 \%$ & Fraction \\
\hline 8 & $1 \%-9 \%$ & Little \\
\hline 9 & $0 \%$ & No at all \\
\hline
\end{tabular}

From the data which is the result of the calculation of descriptive analysis, what needs to be discussed next is the mean or average value. This is intended to determine the condition / description of each aspect studied based on the respondent's answer. To determine the percentage, researchers use.

$$
\mathrm{P}=\frac{\mathrm{NS}}{\mathrm{NH}} \times 100 \%
$$

Information:

$\mathrm{P}$

$$
=\text { Percentage }
$$


NS $=$ Score Score, can be known by dividing the score by the number of respondents

$\mathrm{NH}=$ Expectation Value, can be determined by multiplying the number of question items with the highest score.

To give a category of the average value obtained, the interpretation guidelines used by Suharsimi Arikunto are as follows:

- Good, if the value obtained is at an interval of 76$100 \%$

- Enough, if the value obtained is at an interval of 56$75 \%$

- Less, if the value obtained is at an interval of 40$55 \%$

- Not good, if the value obtained is at an interval of $40 \%$

\section{RESULT AND DISCUSSION}

Harmony State High School is a new school unit (USB), which was established by the City of Poso. The school was founded in 2014 and was inaugurated in 2015 by Drs. H. Muhammad Jusuf Kalla, SE. who was then the vice president of the Republic of Indonesia.

The school principal revealed that the background for giving the name "harmony" to the school was a picture of the success of the Poso District government together with its staff, especially in the field of security so that the Poso community returned to living in harmony and harmony and also the support of Mr. Drs. H. Muhammad Jusuf Kalla, SE, who supported the construction of this school.

Harmoni State High School is on the trans Sulawesi road, Sulewana Village, North Pamona District, Poso Regency, Central Sulawesi Province. Supporting facilities are still regional. The location of Harmoni's Public High School in the north is directly adjacent to the trans Sulawesi road, in the west it is bordered by the Pamona subdistrict office, in the east it is bordered by Puskesmas Sulewana and in the south it is bordered by the dormitory of Palindondaya Vocational School. Harmoni State High School is one of the three high schools in the District of North Pamona

A. Principal's Managerial Ability in Management of Facilities and Infrastructures to Improve the Quality of Education

Analysis of the results of the questionnaire showed that the category of the value obtained was in the good category of $76.67 \%$ with 10 questions distributed to 10 informants. Obtaining a total score of 230 with $\mathrm{NH} 10 \times 3$ $=30$, NS 230: $10=23$ so that the average obtained is NS / $\mathrm{NH} \times 100 \%=76.67 \%$ or in the good category.

The results of research on the principal's managerial ability can be seen from the ability of school principals in planning, coordinating activities, conducting supervision, evaluating activities, holding meetings, making decisions, managing the learning process, organizing administration and regulating administration, students, personnel, facilities and infrastructure and finance.

In compiling a plan, the principal arranges something based on the scale of priorities or things that are most needed by the school proposed by the teacher or the principal. Planning for school needs is generally done at the beginning of the semester or the beginning of a new school year through meetings between teachers, staff, and school principals so that decisions are made together so as not to harm a particular party.

In this case, the role of the school committee is also needed as stated by Mulyasa (2010: 54) namely the school committee has the role as: (1)advisory agency; (2) supporters (supporting agency); (3) controller (controlling agency); (4) mediator with the community in the process of procuring facilities and infrastructure in schools.

Activities undertaken or participated by students ranging from teaching and learning activities (KBM) in the classroom to activities outside the classroom such as scouts, scientific papers, drum bands, sports and OSN and O2SN competitions and other existing activities are always coordinated by the principal of course with the help of the teachers. One example is in activities such as scientific papers participated by schools, principals who also have the ability to write scientific papers specifically guide or teach students who are interested in participating in these activities which will be prepared to take part in district and provincial level competitions. so that for several years following the competition, this school received a number of ratings and awards for the activity. Another example is the OSN (National Science Olympiad) activity, the school principal said that students were selected approximately 6 months before the activity took place to be educated and taught by the teachers according to the subjects they were taking. The departure costs for students are obtained from the collaboration between the school principal and outside parties.

Supervision and evaluation of an activity is always done by the principal through a meeting with the teachers to find out the results of these activities to be used as a basis for better future.In school management, all available resources must be used and utilized optimally. As with human resource management in order to improve the quality of education is very important, this is given that in an organization or educational institution, can advance and develop with the support of human resources. Therefore, every educational institution or organization that wants to develop, must pay attention to human resources and manage them well, in order to create quality education. The human resources in education include the principal, educators (teachers), employees and school committees. Schools are given the authority and responsibility to make decisions according to the needs, abilities and demands of the school and the community or existing stakeholders.

The learning process at the school is also coordinated by the school principal, with the help of the vice principals and the teachers. The learning process at school does not always run smoothly. Therefore, there is a need for the ability of the school to overcome the existing problems, one of the problems lies in the facilities and infrastructure owned by the school. For example some of these schools have a computer room but do not yet have a computer in it to support the learning process so that the principal resolves the problem by using a laptop donated from collaboration with outside parties, collaboration with 
teachers and fellow school principals. so that the learning process can run well, also this school has implemented UNBK in schools well for the past 2 years.

Referring to the thought of Rich [6] who said that: "There are five domains of knowledge that must be possessed by school principals, namely practical knowledge, intellectual, smaal talk, spiritual knowledge and unknown knowledge. Mastery of this knowledge is essential in the implementation of management in schools. Knowledge of work has a high correlation to work performance and work ability has a high correlation to work performance ".

Another problem is that this school has a library space but the books are still limited so the headmaster applies a donation of books from students who will graduate with the thought that their books will not be used again after they graduate because they will enter college. In addition to collaborating with other parties, the principal also conducts entrepreneurial activities which are also taught to students, especially OSIS, who also support school facilities. For example, the student council held a competition between classes at the school which was held at the end of the semester and was always gifted with wall clocks, brooms, etc. which would later be stored in each class so that indirectly educational facilities especially in classrooms had been completed.

One of the funds received by schools that also contributed greatly was BOS funds or school operational assistance. Through the BOS program, the Central Government provides block grants to schools. Schools can use these funds for school operational needs, especially non-personnel operational costs in accordance with the rules set out in the program implementation manual. Permendikbud number 3 of 2019 concerning BOS technical guidelines states that 1) regular BOS is allocated for providing education in schools, 2) the amount of regular BOS allocation received by schools is calculated based on the number of students multiplied by the cost unit, 3) the 2019 regular BOS unit cost for high schools i.e. Rp. 1,400,000.00 (one million four hundred thousand rupiah) per 1 (one) student every 1 (one) year.

The collaboration between the principal and outside parties that is most prominent or has a significant influence on the development of the school is the cooperation with PT. Poso Energy. so some of the facilities and infrastructure owned by the school come from the results of cooperation with PT. Poso Energy is like a dormitory building and its contents, field repairs, educational facilities such as laptops, printers and other assistance. The stages are carried out by the principal based on the results of the interview to be able to work with this company, namely: 1) determining the school's goals in establishing cooperation, 2) knowing what will be given and what will be obtained, 3) seeking personal contact from the company big, 4) making sure to align the goals. In partnering with a larger company requires hard work and cooperation, and lots of patience. Because in general it is not easy to establish cooperation given that in Pamona Utara Subdistrict there are 4 high schools that are also competing for assistance from this cooperation, moreover this school is a new school unit. The agreement made stated in a joint agreement between PT. Poso Energy with Senior High Schools about "CSR activities in the form of supporting facilities and infrastructure to support the teaching and learning process of Harmoni Poso High School". The agreement took effect on November 20, 2015, which was signed in Jakarta. As for Achmad Kalla, acting as the first party and on behalf of PT. Poso Energy and Ms. Yenny Flora Tampa'i as the second party and acted on behalf of Poso Harmoni High School.

The facility and infrastructure assistance referred to are: a) Supporting learning facilities and infrastructure in the classroom; b) Facilities and supporting infrastructure for learning in the laboratory; c) Student dormitory; d) Training on the actual ability and creativity development of teaching staff; e) Means of worship in the school environment.

Assistance received by the school is not in the form of direct money but the company that built the supporting facilities or facilities that have been mutually agreed upon so that the school only co-ordinates the existing development. This was done to minimize the existence of things that are not desirable.

The headmaster said the cooperation was carried out because the school could not always expect funding from the government or BOS (School Operational Assistance) funds because it had a long time to go and also the school principal added that not everything related to the fulfillment of educational facilities and infrastructure in schools must use the funds available at the school because the funds owned by the school will not be sufficient to meet these needs, moreover one of the provisions of the BOS funds is that they are not allowed to build new buildings or rooms, so there is need for additional funds or assistance from other parties as well as the managerial ability of the head schools must be improved so that existing problems can be overcome properly without causing harm. Based on the description that the general problems that occur in schools are caused by lack of facilities and infrastructure owned by the school for the continuation of the learning process so that a good managerial ability of the principal is needed to overcome these things so that the learning process can take place properly so as to improve the quality education in school. $B$. Stages of Facilities and Infrastructure Management

Based on the calculation of the percentage in accordance with the Likert scale, each stage was obtained, namely the planning stage $90.2 \%$, the procurement phase $90.3 \%$, the distribution phase $70.3 \%$, the maintenance phase $78.7 \%$ so that the average maintenance stage was $78.7 \%$ so that the average management phase of facilities and infrastructure carried out by principals in Harmoni State High School is $82.375 \%$ or good. The following table results in the interpretation of data from 15 questions with 10 samples. 
TABLE II. INTERPRETATION OF DATA

\begin{tabular}{|c|c|c|c|c|}
\hline No & Aspect & $\mathrm{NH}$ & NS & NH/NS x $100 \%$ \\
\hline 1 & Planning & $3 \times 3=9$ & $83: 10=8.3$ & $\begin{array}{c}8.3 \times 100 \%=90.2 \% \\
9\end{array}$ \\
\hline 2 & Procurement & $3 \times 3=9$ & $84: 10=8.4$ & $\begin{array}{c}\underline{8.4} \times 100 \%=90.3 \% \\
9\end{array}$ \\
\hline 3 & Distribution & $4 \times 3=12$ & $88: 10=8.8$ & $\begin{array}{c}\underline{8.8} \times 100 \%=70.3 \% \\
12\end{array}$ \\
\hline 4 & Maintenance & $5 \times 3=15$ & $118: 10=11.8$ & $\begin{array}{c}11.8 \times 100 \%=78 . \% \\
15\end{array}$ \\
\hline \multicolumn{3}{|c|}{ Sum } & \multicolumn{2}{|c|}{$329.5 \%$} \\
\hline \multicolumn{3}{|c|}{ Average } & \multicolumn{2}{|c|}{$\underline{329.5}=82.38 \%$} \\
\hline
\end{tabular}

Based on the calculation of the percentage according to the Likert scale, each stage is obtained, namely the planning stage of $90.2 \%$, the procurement phase of $90.3 \%$, the distribution phase of $70.3 \%$, the maintenance stage of $78.7 \%$ so that the average management phase of facilities and infrastructure carried out by the school principal at Harmoni State High School is $82.375 \%$ or good. The following tables interpret the results of data from 15 questions with 10 existing samples:

Facilities and infrastructure are one of the necessary and very important educational resources that are well managed and are an inseparable part of education management. Such as buildings, land, administrative equipment to the facilities used directly in the teaching and learning process in class.

The management standard of Harmoni State High School can be seen in the condition of school facilities and infrastructure recapitulation which is generally in good condition. This indicates that the management found in Harmoni State High School can be said to be standard because the condition of the facilities and infrastructure is in good condition, with the existence of a monitoring and evaluation plan conducted by the Deputy Principal in the field of facilities and infrastructure.

The stages in the management of facilities and infrastructure are divided into several things, namely from the planning stage, the procurement phase, the distribution or distribution stage, the maintenance phase and the control phase. Following is an explanation of the stages of the management of facilities and infrastructure.

C. Education Facilities and Infrastructure Planning

Based on the calculation of the percentage of questionnaires that have been distributed to 10 samples or informants using a Likert scale, the results obtained $90.2 \%$ or equivalent to good predicate, it can be concluded that the planning stage of educational facilities and infrastructure in Harmoni State High School is carried out and implemented by the principal as manager in the school has been going well.

The headmaster said that initially in each fiscal year, the principal along with the teacher and staff prepared a budget plan, the plan was decided together through a meeting with the teacher council. The planned budget is derived from the BOS, Committee, OSIS, P3 budget as well as other businesses through proposals and other assistance that has been programmed from the beginning or in collaboration with other parties. In the preparation of educational facilities and infrastructure planning the principal does not act alone, the principal invites all teachers, administrative staff, and committees to discuss matters to be carried out on a priority scale.

$D$. Procurement of Educational Facilities and Infrastructure

Based on the calculation of the percentage of questionnaires that have been distributed to 10 samples or informants using a Likert scale, the results obtained $90.3 \%$ or equivalent to good predicate, it can be concluded that the procurement phase of educational facilities and infrastructure at Harmoni State High School is conducted and implemented by the principal as manager in the school has been going well.

The fulfillment of facilities and infrastructure is always endeavored every year, through the submission of proposals to the relevant government but not all proposals for the fulfillment of facilities and infrastructure can be accommodated due to budget constraints each year, based on these limitations the school principal always involves the teacher in charge of the facilities and infrastructure as well as the existing treasurer to see the most needed facility, which is always guided by the Regulation of the Minister of National Education of the Republic of Indonesia Number 24 of 2007 concerning Facilities and Infrastructure Standards for Schools. On the other hand, the school principal cooperates with certain parties to be able to help fulfill the existing facilities and infrastructure.

Procurement of educational facilities and infrastructure can be done by buying, renting, and receiving grants from other parties. Ms. Lindo as the deputy head of school facilities and infrastructure said that in Harmoni State High School the provision of educational facilities and infrastructure is carried out by the school through BOS funds, committees, as well as cooperation with other parties, and the procurement of school facilities and infrastructure can also be done by students through OSIS funds (intra-school student organizations). For example regarding the procurement of school furniture such as tables and chairs procurement is done by buying to companies that make chairs and desks. If the procurement of teaching aids, media and practical tools and office equipment with a large amount is held in collaboration 
with other parties, the procurement of school package books can be held by buying by themselves and receiving assistance from the Government. As for other needs such as the needs of tablecloths, serber hands and decorations in the study room provided by students or obtained from the results of the inter-class competition at the end of the semester from OSIS.

E. Distribution or Use of Educational Facilities and Infrastructure

Based on the calculation of the percentage of questionnaires that have been distributed to 10 samples or informants using a Likert scale, $70.3 \%$ results are obtained or equivalent to good predicate, it can be concluded that the distribution stage or use of educational facilities and infrastructure in state high schools The harmony carried out and implemented by the principal as manager in the school has been going well.

Distribution of educational facilities and infrastructure is an activity that involves the distribution or distribution of goods according to the needs of teachers or students for teaching and learning activities. For the distribution of infrastructure, this is done with the approval of the principal who regulates how the distribution of educational infrastructure. Distribution in Harmoni State High School is done evenly without distinguishing differences in achievement between students or other matters. All teachers and students use facilities and infrastructure in accordance with their functions. The use of teaching aids and learning media is also carried out by teachers and students. Teachers and students always optimize the use of educational facilities in teaching and learning activities.

\section{$F$. Maintenance of Educational Facilities and}

Infrastructure

Based on the calculation of the percentage of questionnaires that have been distributed to 10 samples or informants using a Likert scale, the results obtained are $78.7 \%$ or equivalent to good predicate, it can be concluded that the maintenance phase of educational facilities and infrastructure at Harmoni State High School is conducted and implemented by the principal as manager in the school has been going well.

Maintenance is an activity carried out continuously to keep school belongings always in good condition and ready for use. Maintenance of educational facilities and infrastructure has a very important role because with good maintenance, the implementation of education will run well too.

Likewise with Harmoni State High School, the school principal always appealed to the existing facilities and infrastructure to be properly maintained so that they could support the existence of teaching and learning activities. The principal makes efforts to maintain facilities and infrastructure (maintenance, storage and inventory). Substitution of educational facilities is carried out if the educational facilities have been damaged and are not suitable for use. Storage of educational facilities is done regularly. Maintenance is carried out by all parties including students, the board of teachers and the school principal.
In the stage of controlling educational facilities and infrastructure the principal issues policies in managing school facilities and infrastructure. In this case, the principal gives the task to the teacher to help control the educational facilities such as the headmaster determines the teacher who controls the library room, laboratory room, computer room and so on which are under the authority of the principal to be accounted for according to their respective duties .

Based on the explanation above it was concluded that the average percentage of principals' managerial abilities in the management of facilities and infrastructure to improve the quality of education was $82.375 \%$ or in the good category with the highest percentage at the procurement stage of $90.3 \%$ and the lowest percentage at the distribution stage of $70.3 \%$. This shows that in the management of facilities and infrastructure in schools the principal must follow the stages of management properly to be able to manage and manage resources in the school so that the learning process and improving the quality of education can go well.

The above description reinforces the opinion that the management of educational facilities and infrastructure in schools includes the activities of procurement, distribution, use and maintenance, inventory and elimination of all educational facilities and infrastructure [7].

G. Facilities and Infrastructure in Improving the Quality of Education

Improving the quality of education will be achieved if the teaching and learning process held in the classroom is truly effective and useful to achieve the expected knowledge, attitudes and skills. Because basically the teaching and learning process is the core of the overall education process, including educational facilities and infrastructure as one of the elements of educational management that has an important role in the teaching and learning process, educational facilities are things that should not be ignored. Educational facilities and infrastructure are also used to facilitate students' understanding of the material delivered by using appropriate educational facilities and infrastructure in teaching and learning programs to be more effective and efficient. With the educational facilities and infrastructure of teaching and learning activities will become more meaningful and of quality and fun.

Discussing the quality of education is clearly also related to existing academic results, Harmoni State High School every year has a graduate student with a satisfactory value. This can be seen from the final exam scores of students whose average exam results are always included in the 10 highest order ranks for each subject with the lowest grade above the average minimum mark. This school also has an B accreditation value so that graduates can be accepted at state universities (PTN).

A good school building can affect students psychologically in learning so that a comfortable building can increase children's desire to learn in school. Existing learning media is also needed for the continuity of the teaching and learning process especially in the midst of 
increasingly evolving technology that requires several facilities such as LCD, laptops, DVDs and so on so that students can freely learn without obstacles. Internet network is also needed by every school, for example in Harmoni State High School, it has an internet network that can be accessed by all teaching staff and students so that it is used for the continuation of the learning process that goes well. On the other hand, examples of tools that can improve student learning outcomes are the availability of complete and accessible books in the library so that students can add insight by reading. Not only that, students also need facilities and infrastructure that can develop their interests and talents such as this school already has a basketball court facility that can also be used for other sports, dance halls, halls that can also be used for table tennis , drum band equipment facilities, etc. that will directly develop their interests and talents that can have an impact on their non-academic achievements.

With adequate facilities and infrastructure, students will have high motivation to study seriously so that the teaching and learning process can run smoothly, regularly, effectively and efficiently and can produce student achievement in accordance with the expected goals.

The achievements are divided into two things namely academic and non-academic achievements. Harmoni State High School has quite a lot of achievements at the district and provincial level, for example such as the OSN (National Science Olympiad) competition, which since its inauguration in 2015 this school has always followed the competition at the district level and always has representatives to the provinces every year. Also contests such as district level scientific papers as well as district and provincial level O2SN competitions.

Some of the competitions participated by the school consisted of academic and non-academic achievements. The most prominent academic setups in the OSN (National Science Olympiad) activities include OSN in economics, earth, mathematics, physics, biology, astronomy, geography, chemistry, and ICT which have been participated in several times at the provincial level, namely in 2015 This school has been a representative in economics since it was just inaugurated. In 2016, the school will become a representative of the provincial OSN in the fields of earth, biology, astronomy and geography. In 2017, this school became a representative of OSN at the provincial level in the fields of earth and astronomy, in 2018 becoming a representative of biology, mathematics, chemistry, and geography and in 2019 becoming a provincial OSN representative in biology. Other academic achievements that they often take part in each year are scientific papers and English debates, which on average each year win between 1 (one) to (three) champions 3 .

Non-academic achievements, namely in 2015, including 1 champion walking, second place in the district level anti-drug slogans, 1st place in the vocal group, 2nd place in ongga bale. In 2016, 1st place FLS2N paired dance at district level, 1st place PKS Competition, 1st place vocal group competition, 2nd gymnastics champion, 1st place anti-drug ambassador, 1st place FLS2N poetry creation, 3rd place FLS2N art craft, 2nd place FLS2N language debate Indonesia, 3rd place O2SN high jump, 4th place marathon $5 \mathrm{Km}$ race, 2nd place FLS2N short film, 4th place O2SN chess game, 1st place solo race, and 3rd place O2SN long jump. In 2017 won 1st place in PKS competition, 1st place in torompio dance, 2nd place in bgga bale son of intelligence, 3rd place in volley ball and became a messenger in national student volley ball, 1 st in $\mathrm{O} 2 \mathrm{SN}$ in karate field, 1st place in FLS2N poster design, 1st place in election Putri Danau Poso Pariwisaa, Central Sulawesi, became a messenger at the Regional Student Sports Week (POPDA), then in 2018 won 2nd place for O2SN badminton, 1st place for Lore Lindu megalith cultural camp activities, and this year in 2019 this school won 3rd place in tennis Porprov table, champion 6 of porprov sand volleyball, took part in the national Kartika sakawira (scout) event, was the second winner in poetry creation and the first winner in the story writing competition (Mosintuwu festival) and there were still a number of activities to be followed by the upcoming school.

The description is supported by Soedijarto's opinion (2013: 24) which states that: "An education is seen as having a good quality measured by its role in contributing to the intellectual life of the nation and advancing national culture, is education that has succeeded in forming smart, character, moral, and personality young people. For this reason, it is necessary to design an education system that is able to create a pleasant atmosphere and learning process, stimulate and challenge students to develop themselves optimally in accordance with their talents and abilities, this is a democratic education.

\section{CONCLUSION}

Based on the results of the data described above, from the results of the research conducted, conclusions can be drawn as follows:

- A principle and knowledge possessed by the principal greatly influences the principal's managerial ability because the implementation of the principal's tasks and functions of the principal does not sufficiently rely on practical actions and fragmentation, but is based on knowledge of intelligent management and leadership. The nature of knowledge is all that the principal knows about a particular object.

- he ability of principals to cooperate with outsiders is also very much needed, given that the school is an organization that basically also needs help from other parties as well as expecting assistance from the government because the government cannot directly meet the needs of the school also if it considers that the school is still relatively new with a relatively small number of students compared to other schools as happened in Harmoni's Public High School.

- The principal conducts the planning stage in the management of facilities and infrastructure together with the teacher council, administrative staff and existing committees to discuss the needs of the school which are urgently needed so that they can be structured and systematic and decision-making is 
carried out jointly without any party being disadvantaged.

- The procurement of school facilities and infrastructure is carried out through a number of things such as buying from school funds, borrowing, and obtaining existing donations both from the collaboration between the school and other parties and procurement by students and teachers.

- The distribution is carried out by the school principal evenly without prioritizing certain parties and also the use of facilities and infrastructure made by teachers and students has been used as it should.

- Maintenance is carried out by all teachers and students who are coordinated by the person in charge of each infrastructure that has been determined and will be accounted to the principal. The control in the form of policies issued by the principal is done in the common interest so that the existing infrastructure can be used properly.

- Harmoni State High School every year has graduate students with satisfactory grades. This can be seen from the final exam scores of students whose average exam results always fall into the 10 highest order ranks in each subject with the lowest score above the average minimum mark in Poso District. The school also won many academic and non-academic achievements at the sub-district, district and provincial levels.

Based on the results of this study the researchers suggest several things as well as recommendations, namely:

- The principal or teacher should make the management of educational facilities and infrastructure as one of the ways in the provision of knowledge, skills and school development that must be carried out effectively and efficiently in accordance with the objectives expected to improve the quality of learning.

- Teachers should also participate in realizing improved learning quality through the empowerment of facilities and infrastructure and supporting the work programs of principals, especially those related to facilities and infrastructure.

- Facilities and Infrastructure are tools that can help the success of education for that management and utilization of existing facilities and infrastructure must be implemented properly so that the results obtained are optimal.

- For students management of educational facilities and infrastructure should be able to improve the quality of good learning, in order to support the achievement of school goals that have been set.

- In the distribution phase or the use that is carried out by all schools should be used effectively and efficiently to avoid waste in the school. The use must also pay attention to school policies that have been determined.

- In the maintenance phase it should be done routinely and periodically so that the facilities and infrastructure that are owned can be used properly to support the learning process at school.

- In improving the quality of education in schools, existing achievements can be maintained and developed to achieve educational goals in schools. Students are always accustomed to developing their interests and talents and abilities through existing learning so that they can make achievements.

\section{REFERENCES}

[1] Kemendiknas, "Peraturan Menteri Pendidikan Nasional No. 13 tahun 2007 tentang Standar Kepala Sekolah/Madrasah." Kemendiknas, Jakarta, 2007.

[2] M. Novita, "Sarana Dan Prasarana Yang Baik Menjadi Bagian Ujung Tombak Keberhasilan Lembaga Pendidikan Islam," NUR EL-ISLAM J. Pendidik. dan Sos. Keagamaan, vol. 4, no. 2, pp. 98-129, 2017.

[3] Prastyawan, "MANAJEMEN SARANA DAN PRASARANA PENDIDIKAN Prastyawan 1," Al-Hikmah, vol. 6, no. 1, pp. 3346, 2016.

[4] A. M. Q. Varela, M. P. Méxas, and G. M. Drumond, "The scenario of software asset management (SAM) in large and midsize companies," Indep. J. Manag. Prod., vol. 9, no. 2, p. 301, 2018.

[5] P. S. S. Aravinth, K. D. Mydeen, R. Divya, and M. Priyadharshini, "IT Infrastructure Management and Maintenance System - A Positive Climate Architecture ( ITIMMS )," J. Aplplied Sci. Eng. Methodol., vol. 1, no. 1, pp. 100-103, 2015.

[6] S. Wulandari, "Kinerja Kepala Sekolah dalam Pengelolaan Sarana dan Prasarana Pendidikan di Mts Khazanah Kebajikan Pondok Cabe Ilir Pamulang," UIN Jakarta, 2013.

[7] I. Bafadal, Manajemen Perlengkapan Sekolah. Jakarta: PT. Bumi Aksara, 2004. 